\title{
Optimasi Kandungan Gizi Tepung Ubi jalar (Ipomoea batatas L.) Terfermentasi Ditinjau dari Dosis Penambahan Inokulum Angkak Serta Aplikasinya dalam Pembuatan Mie Basah
}

\author{
Nutritional Content Optimization of Fermented Sweet Potato Flour (Ipomoea batatas L.) as Revealed by \\ Various Doses Addition of The Inoculum Red Yeast Rice and Its Application on Wet Noodles \\ Yosia Adi Susetyo*, Sri Hartini, Margareta Novian Cahyanti \\ Program Studi Kimia, Fakultas Sains dan Matematika, Universitas Kristen Satya Wacana, Salatiga \\ *Korespodensi dengan penulis (adi.yosia1995@gmail.com) \\ Artikel ini dikirim pada tanggal 8 April 2016 dan dinyatakan diterima tanggal 15 Mei 2016. Artikel ini juga dipublikasi secara online melalui \\ www.jatp.ift.or.id. Hak cipta dilindungi undang-undang. Dilarang diperbanyak untuk tujuan komersial. \\ Diproduksi oleh Indonesian Food Technologists ${ }^{\circledR}(02016$
}

\begin{abstract}
Abstrak
Ubi jalar memiliki potensi sebagai bahan pangan berbasis sumber daya lokal yang dapat dimanfaatkan menjadi produk tepung ubi jalar terfermentasi. Tujuan penelitian ini adalah menghasilkan tepung ubi terfermentasi yang optimal ditinjau dari besarnya konsentrasi substrat ubi jalar dan penambahan inokulum angkak. Fermentasi dilakukan menggunakan inokulum angkak dengan berbagai dosis konsentrasi yaitu $0 \%, 5 \%, 10 \%, 15 \%$ dan $20 \%$. Analisis terhadap tepung ubi jalar terfermentasi meliputi pengukuran kadar air, kadar abu, karbohidrat, protein, lemak, serat, derajat asam, aktivitas antioksidan serta analisa organoleptik. Tepung dari nisbah yang paling optimal diaplikasikan dalam pembuatan mie basah dengan subtitusi tepung ubi jalar terfermentasi sebesar $10 \%, 20 \%$, $30 \%, 40 \%$ dan $50 \%$. Hasil penelitian menunjukkan penambahan inokulum angkak dengan dosis 5\% menghasilkan fermentasi yang optimal, dengan kandungan kadar air sebesar 7,19\%, kadar abu 2,44\%, karbohidrat $49,77 \%$, protein 1,62\%, lemak 1,38\%, serat kasar 4,59\%, derajat asam 9,27 NaOH 0,1 N/100 g dan memiliki aktivitas antioksidan yang mampu menghambat radikal bebas sebesar $48,12 \%$. Uji organoleptik dengan 25 panelis menunjukkan bahwa produk mie basah yang paling disukai adalah dari subtitusi tepung ubi jalar terfermentasi sebesar $10 \%$.
\end{abstract}

Kata kunci: ubi jalar, proksimat, organoleptik, fermentasi, mie basah

\begin{abstract}
Sweet potato has potency as a food-based local resources that can be utilized as fermented sweet potato flour. This research was aimed to produce the optimum fermented sweet potato flour as revealed by concentration addition of red yeast rice. Fermentation was carried out using inoculum red yeast rice with various doses $0 \%, 5 \%$, $10 \%, 15 \%$ and $20 \%$. Analysis of fermented sweet potato flour includes content of moisture, ash, carbohydrates, protein, fat, fiber as well as antioxidant activity and analysis of organoleptic. The most optimal flour was applied in manufacturing of wet noodles with varied substitution of fermented sweet potato flour are $10 \%, 20 \%, 30 \%, 40 \%$ and $50 \%$. The results showed the addition of red yeast rice concentration $5 \%$ is the most optimal fermentation with content of moisture $7.19 \%$, ash $2.44 \%$, carbohydrate $49.77 \%$, protein $1.62 \%$, fat $1.38 \%$, fiber $4.59 \%$, acidity 9.27 $\mathrm{NaOH} 0.1 \mathrm{~N} / 100 \mathrm{~g}$, and has $48.12 \%$ of the ability to inhibit free radicals scavenging, as well. Organoleptic was done by 25 panelists, and the results showed that wet noodles was the most preferred with substitution of fermented sweet potato flour $10 \%$.
\end{abstract}

Keywords: sweet potato, proximate analyses, organoleptic, fermentation, wet noodle.

\section{Pendahuluan}

Ubi jalar (Ipomoea batatas L.) merupakan salah satu tanaman palawija yang banyak dijumpai di Indonesia. Luas lahan ubi jalar di Indonesia pada tahun 2009 mencapai 174.561 ha dengan produksi mencapai sekitar 1.947.311 ton (Karleen, 2010). Ubi jalar memiliki potensi sebagai bahan pangan berbasis sumber daya lokal. Pemerintah telah mengeluarkan Kebijakan Percepatan Penganekaragaman Konsumsi Pangan Berbasis Sumber Daya Lokal yang tertera dalam Peraturan Presiden No. 22 tahun 2009. Pemanfaatan ubi jalar kurang diminati oleh masyarakat karena dinilai identik dengan makanan masyarakat miskin sehingga mengakibatkan ubi jalar kurang populer pada masyarakat golongan menengah ke atas. Kalangan anak muda juga terkesan sangat jarang mengkonsumsi ubi jalar dalam kesehariannya.

Ubi jalar (Ipomoea batatas L.) merupakan salah satu komoditas pertanian yang memiliki potensi sebagai bahan pangan, bahan baku industri, dan pakan ternak. Beberapa peneliti telah berhasil membuktikan bahwa ubi jalar merupakan jenis bahan pangan modern yang dapat diubah menjadi produk tepung yang kemudian dapat digunakan untuk memproduksi berbagai jenis bahan pangan seperti kue kering, brownies, mie dan lain-lain (Zuraida dan Supriati, 2001).

Komoditas ubi jalar sangat layak dipertimbangkan dalam menunjang program diversifikasi pangan yang berbasis tepung karena memiliki kandungan nutrisi yang baik, umur tanam yang relatif pendek, serta hasil produksi yang tinggi. Ubi jalar 
memiliki tekstur yang lunak, kadar air yang tinggi dan memiliki sifat mudah rusak oleh pengaruh mekanis. Pengolahan ubi jalar menjadi tepung merupakan salah satu upaya pengawetan ubi jalar. Selain itu, juga merupakan upaya peningkatan daya guna ubi jalar supaya dapat dimanfaatkan sebagai bahan baku industri pangan (Karleen, 2010).

Fermentasi merupakan proses produksi energi dalam sel dalam keadaan anaerobik atau tanpa oksigen. Dalam proses fermentasi terjadi proses perubahan karbohidrat menjadi alkohol dan karbon dioksida atau asam amino organik menggunakan ragi, bakteri, fungi atau kombinasi dari ketiganya di dalam kondisi anaerobik. Proses fermentasi pada ubi jalar dapat dilakukan dengan menggunakan jamur Monascus sp. dalam bentuk angkak. Angkak dapat digunakan sebagai pewarna makanan karena sifat pigmennya yang stabil, memiliki kelarutan yang tinggi, tidak mengandung racun serta mudah dicerna di dalam tubuh. Pigmen angkak juga memiliki aktivitas sebagai antimikroba sehingga dapat memperpanjang masa simpan makanan, dengan menggunakan angkak sebagai inokulum, tepung ubi jalar yang dihasilkan akan memiliki pewarna yang alami sehingga dapat mencegah penggunaan pewarna buatan atau sintetis yang berbahaya jika dikonsumsi.

Sejauh ini penelitian tentang fermentasi dengan Monascus sp. telah dilakukan dan digunakan untuk memperbaiki nilai gizi pada pakan ternak, namun fermentasi dengan inokulum angkak pada substrat ubi jalar belum pernah dilakukan. Berdasarkan penelitian sebelumnya yang dilakukan Kusumawati et al. (2005) yang meneliti pembentukan warna pada MonascusNata Kompleks dengan substrat kombinasi dari ekstrak beras, ampas tahu dan dedak padi menggunakan konsentrasi inokulum Monascus purpureus sebesar 10 $\% \mathrm{w} / \mathrm{w}$.

Nuraini et al. (2009) mengatakan juga bahwa penambahan inokulum dengan dosis $10 \% \mathrm{w} / \mathrm{w}$ dapat meningkatkan kandungan monakolin dan protein kasar pada bahan pakan limbah pertanian seperti ampas sagu, kulit umbi ubi kayu, dedak dan ampas tahu. Suatu molekul protein tersusun dari sejumlah asam amino, semakin meningkatnya kadar protein dalam proses fermentasi akan meningkatkan kandungan asam amino. Rusli, (2011) mengatakan proses fermentasi dengan jamur Monascus purpureus meningkatkan beberapa jenis asam amino seperti Aspartat, Glutamat, Serin, Glysin, Histidin, Arginin, Threonin, Alanin, Prolin, Tirosin, Valin, Methionin, Sistein, Iso-leusin, Leusin, Penil alanine dan Lysin.

Percobaan yang dilakukan Suslina et al. (2011) yang meneliti pengaruh konsentrasi penambahan campuran ampas tahu dan ampas sagu terfermentasi Monascus purpureus terhadap kandungan gizi pada pakan ternak atau ransum diperoleh nilai gizi yang paling optimal pada penambahan ampas sagu dan ampas tahu terfermentasi Monascus purpureus sebesar $15 \%$ w/w. Selain jumlah mikroorganisme waktu fermentasi juga mempengaruhi pertumbuhan mikroorganisme dalam substrat. Berdasarkan penelitian
Dwinaningsih, (2010) yang meneliti pengaruh lama fermentasi campuran angkak dan ragi dalam pembutan tempe, diperoleh peningkatan kandungan protein yang maksimal pada lama fermentasi 48 jam.

Berdasarkan penelitian yang telah dilakukan sebelumnya maka penelitian ini bertujuan untuk mencari nisbah antara substrat ubi jalar dan penambahan inokulum angkak yang tepat sehingga diperoleh produk tepung ubi jalar terfermentasi yang optimal ditinjau dari kadar air, kadar abu, karbohidrat, protein, lemak, serat, derajat asam dan aktivitas antioksidan. Dari nisbah yang optimal, tepung ubi jalar terfermentasi diaplikasikan dalam pembuatan mie basah dan dilakukan analisa organoleptik. Manfaat dari penelitian ini yaitu menghasilkan tepung alternatif berbahan dasar ubi jalar yang memiliki kandungan gizi optimal ditinjau dari kadar air, kadar abu, karbohidrat, protein, lemak, serat, derajat asam dan aktivitas antioksidan yang dapat diaplikasikan menjadi berbagai jenis produk pangan salah satunya yaitu mie basah.

\section{Materi dan Metode \\ Materi}

Sampel yang digunakan yaitu ubi jalar dan angkak yang dibeli di Pasar Salatiga dan sekitarnya. Bahan kimia yang digunakan antara lain: Indikator Merah Metil (MM), indikator Metil Biru (MB), indikator Phenol Phtalein (PP), 1,1-diphenyl-2-pycrylhydrazil (DPPH) (Sigma Chemical Co. St. Louis USA), $\mathrm{H}_{3} \mathrm{BO}_{3}$, $\mathrm{HCl}, \mathrm{NaOH}$, heksana, $\mathrm{Na}_{2} \mathrm{SO}_{4}, \mathrm{Na}_{2} \mathrm{CO}_{3}$ anhidrat, $\mathrm{CuSO}_{4} .5 \mathrm{H}_{2} \mathrm{O}, \mathrm{KI}, \mathrm{H}_{2} \mathrm{SO}_{4}, \mathrm{Na}_{2} \mathrm{~S}_{2} \mathrm{O}_{3}$, kanji, $\mathrm{CH}_{3} \mathrm{COOH}$, asam sitrat $\left(\mathrm{C}_{6} \mathrm{H}_{8} \mathrm{O}_{7}\right)$, etanol, metanol. Peralatan yang dipakai dalam penelitian antara lain: furnace, drying carbinet, spektrofotometer mini Shimadzu (1240 made in Japan), Moisture analyzer (MB25 Corp., USA), neraca analitis 4 digit (Ohaus Pioner Balance PA214 Corp., USA), neraca analitis 2 digit (Ohaus TAJ602, Ohaus Corp., USA).

Penelitian berlangsung pada bulan September 2015-Februari 2016. Penelitan meliputi proses fermentasi, penepungan, analisa kandungan gizi tepung dan pengaplikasian tepung menjadi mie basah. Analisa kandungan gizi pada tepung ubi jalar terfermentasi meliputi pengukuran kadar air, kadar abu, karbohidrat, protein, lemak dan analisa organoleptik pada produk mie basah.

\section{Pembuatan Tepung}

Ubi jalar dicuci dengan air untuk menghilangkan kotoran dan tanah yang masih melekat kemudian dikukus selama \pm 60 menit setelah itu dikupas kulitnya dan bagian-bagian yang cacat dibuang. Ubi jalar dipotong kecil-kecil kemudian ditambah angkak dengan dosis $0 \% \mathrm{w} / \mathrm{w}$ (sebagai kontrol), $5 \% \mathrm{w} / \mathrm{w}, 10 \% \mathrm{w} / \mathrm{w}$, $15 \% \mathrm{w} / \mathrm{w}$ dan $20 \% \mathrm{w} / \mathrm{w}$ kemudian dikemas di dalam plastik setelah itu difermentasi pada suhu ruang dengan lama fermentasi 48 jam. Setelah proses fermentasi selesai, dilakukan pengeringan menggunakan drying carbinet pada suhu $50^{\circ} \mathrm{C}$ sampai kering. Setelah kering, irisan dihancurkan dan diayak sampai menjadi tepung dengan tingkat kehalusan 61 mesh. 


\section{Pengukuran Kadar Air}

Sebanyak 1,015 gram tepung ubi jalar dimasukkan ke dalam moisture analyzer, selanjutnya ditunggu beberapa menit hingga proses penghilangan kandungan air dalam sampel selesai, kemudian dicatat hasil pengukuran meliputi persen kadar air dan massa sisa sampel setelah pemanasan (dalam gram). Kadar air dihitung berdasarkan perhitungan sebagaimana berikut ini:

$\left[\left(\frac{\text { Massa sampel }- \text { Massa sampel setelah pemanasan }}{\text { Massa sampel }}\right)\right]$ x100\%

\section{Pengukuran Kadar Abu}

Sebanyak 1 gram tepung ubi jalar ditimbang ke dalam cawan porselin yang sudah diketahui massanya, kemudian diabukan dalam furnace pada suhu $550^{\circ} \mathrm{C}$ sampai pengabuan sempurna (SNI, 1992 yang dimodifikasi). Proses selanjutnya adalah pendinginan dalam desikator setelah itu ditimbang dan dilakukan perhitungan kadar abu menggunakan rumus:

$$
\frac{\text { cawan }+ \text { abu }(\mathrm{g})-\text { cawan kosong }(\mathrm{g})}{\text { Massa sampel }(\mathrm{g})} \times 100 \%
$$

\section{Pengukuran Karbohidrat}

Pereaksi Luff-Schoorl dibuat dengan melarutkan 143,8 gram $\mathrm{Na}_{2} \mathrm{CO}_{3}$ anhidrat dalam $300 \mathrm{~mL}$ akuades sambil diaduk kemudian ditambahkan 50 gram asam sitrat $\left(\mathrm{C}_{6} \mathrm{H}_{8} \mathrm{O}_{7}\right)$ yang telah dilarutkan dengan $50 \mathrm{~mL}$ akuades kemudian ditambahkan sebanyak 25 gram $\mathrm{CuSO}_{4} .5 \mathrm{H}_{2} \mathrm{O}$ yang telah dilarutkan dengan $100 \mathrm{~mL}$ akuades. Larutan dipindahkan ke dalam labu 1 liter ditepatkan dengan akuades sampai garis tera dan dikocok. Larutan dibiarkan semalaman dan disaring bila perlu (SNI, 1992).

Larutan Luff-Schrool sebelum digunakan dilakukan pengujian kepekatan yaitu dengan memipetkan sebanyak $25 \mathrm{~mL}$ larutan Luff kemudian ditambah dengan 3 gram $\mathrm{KI}$ dan $25 \mathrm{~mL}$ larutan $\mathrm{H}_{2} \mathrm{SO}_{4} 6$ $\mathrm{N}$ kemudian dititrasi dengan natrium thiosulfat $0,1 \mathrm{M}$ dengan indikator kanji $5 \%$. Larutan natrium thiosulfat $\left(\mathrm{Na}_{2} \mathrm{~S}_{2} \mathrm{O}_{3}\right)$ yang dipergunakan untuk titrasi harus $25 \pm 2$ $\mathrm{mL}$.

Sebanyak 1 gram tepung ubi jalar dimasukkan ke dalam erlenmeyer, kemudian ditambahkan $40 \mathrm{~mL} \mathrm{HCl}$ $3 \%$, setelah itu dididihkan dengan pendingin tegak selama 3 jam, setelah proses pemanasan selesai sampel didinginkan dan dinetralkan dengan $\mathrm{NaOH}$ $30 \%$, kemudian ditambahkan sedikit $\mathrm{CH}_{3} \mathrm{COOH} 3 \%$ agar suasana larutan agak sedikit asam. Larutan dipindahkan ke dalam labu ukur $100 \mathrm{~mL}$ dan digenapkan hingga garis tera kemudian disaring. $10 \mathrm{~mL}$ hasil penyaringan dipipetkan dalam erlenmeyer, kemudian ditambahkan $25 \mathrm{~mL}$ larutan luff, $15 \mathrm{~mL}$ akuades dan beberapa batu didih. Campuran dipanaskan dan diusahakan larutan dapat mendidih dalam waktu 3 menit, dididihkan terus hingga tepat 10 menit (dihitung saat mulai mendidih). Setalah proses pemanasan selesai dengan cepat didinginkan dalam bak berisi es, larutan yang sudah dingin ditambahkan $15 \mathrm{~mL}$ larutan $\mathrm{KI} 20 \%$ dan $25 \mathrm{~mL} \mathrm{H}_{2} \mathrm{SO}_{4} 25 \%$ perlahan-lahan. Larutan ditambahkan indikator kanji
$0,5 \%$ kemudian dititrasi dengan larutan thiosulfat $0,1 \mathrm{~N}$. Kadar karbohidrat $=($ blanko - penitar $) \times \mathrm{N}$ thiosulfat $\times$ 10

Kemudian dilihat dalam daftar Luff Schoorl berapa $\mathrm{mg}$ gula yang terkandung untuk $\mathrm{mL}$ thiosulfat yang digunakan. Kadar glukosa dihitung dengan rumus: Glukosa yang terkandung $x$ Faktor pengenceran $x 100 \%$. Massa sampel (g)

Perhitungan kadar karbohidrat (b/b) dihitung dengan perkalian antara 0,90 dengan kadar glukosa.

\section{Penentuan Kadar Protein}

Sebanyak 1 gram tepung ubi jalar dimasukkan dalam labu Kjedahl $100 \mathrm{~mL}$ dan ditambah $10 \mathrm{~mL} \mathrm{H}_{2} \mathrm{SO}_{4}$ pekat dan $5 \mathrm{~g} \mathrm{Na}_{2} \mathrm{SO}_{4}$. Setelah itu, dipanaskan dengan bunsen api dalam lemari asam. Pemanasan diakhiri setelah cairan menjadi jernih atau tidak berwarna (destruksi). Sampel yang telah didestruksi ditambah dengan $10 \mathrm{~mL}$ akuades, lalu dimasukkan dalam alat distilasi dan ditambah $35 \mathrm{~mL}$ larutan $\mathrm{NaOH}-\mathrm{Na}_{2} \mathrm{~S}_{2} \mathrm{O}_{3}$. Distilat ditampung dalam erlenmeyer $100 \mathrm{~mL}$ yang berisi $25 \mathrm{~mL}$ larutan jenuh asam borat dan beberapa tetes indikator metil merah-metil biru. Distilasi dihentikan setelah terjadi perubahan warna merah muda menjadi hijau. Larutan yang diperoleh dititrasi dengan $\mathrm{HCl}$ 0,02 M standar (Sudarmadji et al., 1997). Kadar protein total (\%) dihitung menggunakan rumus :

$$
\frac{m L H C l x M \text { HClx } 14,008 \times 6,25 \times 100 \%}{\text { massa sampel }(m g)}
$$

\section{Pengukuran Kadar Lemak}

Sampel tepung ubi jalar ditimbang sebanyak 1,5 gram di dalam gelas piala, kemudian ditambahkan 30 $\mathrm{mL} \mathrm{HCl} 25 \%$ dan $20 \mathrm{~mL}$ akuades serta beberapa batu didih. Gelas piala ditutup dengan menggunakan kaca arloji dan dididihkan selama 15 menit. Larutan dalam keadaan panas disaring dan dicuci menggunakan air panas hingga bebas asam. Kertas saring dikeringkan pada suhu $100-105^{\circ} \mathrm{C}$, kemudian dimasukkan ke dalam kertas saring pembungkus (paper thimble) dan diekstrak dengan heksana selama 5 jam pada suhu \pm $70{ }^{\circ} \mathrm{C}$. Pelarut heksana disulingkan kembali dan ekstrak lemak dikeringkan pada suhu $100-105^{\circ} \mathrm{C}$ (SNI, 1992 yang dimodifikasi). Ekstrak lemak didinginkan dan ditimbang (dalam satuan gram), proses pengeringan diulangi hingga diperoleh massa tetap. Kadar lemak $(\% \mathrm{~b} / \mathrm{b})$ dihitung menggunakan rumus :

Massa labu dengan lemak - Massa labu tanpa lemak Massa sampel

\section{Pengukuran Kadar Serat}

Sebanyak 3 gram tepung ubi jalar dimasukkan ke dalam erlenmeyer $500 \mathrm{~mL}$, ditambahkan $50 \mathrm{~mL}$ larutan $\mathrm{H}_{2} \mathrm{SO}_{4} 1,25 \%$ kemudian dididihkan selama 30 menit dengan pendingin tegak, setelah itu ditambahkan

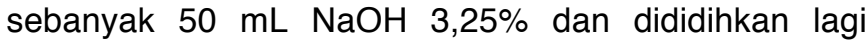
selama 30 menit. Setelah proses pemanasan selesai dengan cepat disaring dengan corong Buchner yang berisi kertas saring yang telah dikeringkan dan diketahui massanya setelah itu dicuci endapan pada kertas saring berturut-turut dengan $\mathrm{H}_{2} \mathrm{SO}_{4} \quad 1,25 \%$ panas, air panas dan etanol $96 \%$. Kertas saring 
kemudian diangkat beserta isinya, dimasukkan ke dalam kotak timbang yang telah diketahui bobotnya, dikeringkan pada suhu $105^{\circ} \mathrm{C}$ didinginkan dalam desikator setelah itu ditimbang sampai bobot tetap (SNI, 1992 yang dimodifikasi). Serat kasar (\%) dihitung menggunakan rumus :

$\frac{\text { Massa kertas saring }+ \text { serat }- \text { Massa kertas saring }}{\text { Massa Sampel }} \times 100 \%$

\section{Derajat Asam}

Sebanyak $10 \mathrm{~g}$ tepung ubi jalar dimasukkan dalam erlenmeyer $250 \mathrm{~mL}$. Selanjutnya, sampel ditambah $100 \mathrm{~mL}$ etanol $95 \%$ dan dibiarkan selama 24 jam sambil sekali - kali digoyangkan kemudian disaring. Selanjutnya $50 \mathrm{~mL}$ sampel hasil saringan dititrasi dengan $\mathrm{NaOH}$ 0,05 $\mathrm{M}$ dengan menggunakan indikator fenolftalein (SNI, 2011). Titrasi berakhir setelah warna larutan menjadi merah muda. Derajat asam dihitung menggunakan rumus:

$$
\frac{m L N a O H \times M N a O H \times \text { faktor prosedur }\left(\frac{100}{50}\right) \times 100}{\text { massa sampel }(g)} \times A
$$

Huruf A sebagaimana tercantum dalam rumus tersebut adalah jumlah (dalam ml) NaOH/100 g sampel.

\section{Analisa Antioksidan}

Analisa antioksidan dilakukan dengan menggunakan metode Penangkap Radikal Bebas DPPH. 1 gram tepung ubi jalar diekstak dalam $100 \mathrm{~mL}$ metanol kemudian hasil ekstraksi diambil sebanyak 15 $\mathrm{mL}$ dan diencerkan menjadi $25 \mathrm{~mL}$. Dari hasil pengenceran diambil sebanyak $1 \mathrm{~mL}$ kemudian ditambahkan dengan larutan DPPH 0,2 mM sebanyak 2 $\mathrm{ml}$ sehingga volume total menjadi $3 \mathrm{ml}$. Pembuatan blanko dibuat dengan mengambil $1 \mathrm{~mL}$ metanol kemudian ditambakan $2 \mathrm{~mL}$ DPPH $0,2 \mathrm{mM}$, setelah itu diinkubasi pada suhu ruang selama 30 menit, selanjutnya serapannya diukur dengan spektrofotometer UV-VIS pada panjang gelombang 517 nm (Prabowo, 2009 yang dimodifikasi). Prosentase hambatan dihitung dengan rumus :

$$
\frac{\text { Absorbansi blanko - Absorbansi sampel }}{\text { Absorbansi blanko }} \times 100 \%
$$

\section{Metode Pembuatan Mie Basah}

Tepung ubi jalar terfermentasi dicampurkan ke dalam tepung terigu dengan berbagai subtitusi (10-50) $\%$, dengan berat total tepung 80 gram, kemudian campuran tepung ditambah 25 gram telur dan sedikt air, sambil diuleni selama kira-kira 20 menit sampai terbentuk adonan yang kalis. Adonan didiamkan selama 10 menit kemudian dicetak dengan cetakan mie dan direbus selama 5 menit dalam air yang telah ditambah $5 \mathrm{ml}$ minyak goreng, lalu mie diangkat dan ditiriskan.

\section{Uji Organoleptik}

Uji organoleptik meliputi warna, aroma, rasa dan tekstur mie, dilakukan dengan uji kesukaan atau uji hedonik. Sampel berupa mie yang telah direbus, dengan 25 orang panelis. Skala hedonik yang dipakai adalah 1 (sangat tidak suka), 2 (tidak suka), 3 (agak suka), 4 (suka), 5 (sangat suka).

\begin{tabular}{|c|c|c|c|c|c|}
\hline & \multicolumn{5}{|c|}{ Konsentrasi Penambahan Angkak } \\
\hline & $0 \%$ & $5 \%$ & $10 \%$ & $15 \%$ & $20 \%$ \\
\hline $\begin{array}{l}\text { Kadar Air } \\
(\% \pm \text { SE) }\end{array}$ & $6,50 \pm 1,17$ & $7,19 \pm 1,48$ & $7,98 \pm 0,51$ & $7,29 \pm 0,77$ & $6,60 \pm 1,23$ \\
\hline$W=1,94$ & a & a & a & a & a \\
\hline $\begin{array}{c}\text { Kadar Abu } \\
(\% \pm \text { SE) }\end{array}$ & $2,68 \pm 0,42$ & $2,44 \pm 0,65$ & $1,98 \pm 0,53$ & $1,80 \pm 0,48$ & $1,63 \pm 0,36$ \\
\hline$W=0,77$ & c & $\mathrm{bc}$ & $a b c$ & $a b$ & a \\
\hline $\begin{array}{c}\text { Karbohidrat } \\
(\% \pm \mathrm{SE})\end{array}$ & $49,86 \pm 4,18$ & $49,77 \pm 4,76$ & $48,54 \pm 4,86$ & $49,01 \pm 4,56$ & $50,03 \pm 4,27$ \\
\hline$W=1,39$ & $a b$ & $a b$ & a & $a b$ & $\mathrm{~b}$ \\
\hline $\begin{array}{l}\text { Protein } \\
(\% \pm \text { SE) }\end{array}$ & $0,52 \pm 0,09$ & $1,62 \pm 0,63$ & $1,44 \pm 0,45$ & $1,41 \pm 0,58$ & $1,27 \pm 0,33$ \\
\hline$W=1,00$ & a & $\mathrm{b}$ & $a b$ & $a b$ & $a b$ \\
\hline $\begin{array}{l}\text { Lemak } \\
(\% \pm \text { SE) }\end{array}$ & $0,79 \pm 0,19$ & $1,38 \pm 0,34$ & $2,33 \pm 0,58$ & $2,48 \pm 0,43$ & $2,76 \pm 0,65$ \\
\hline$W=0,91$ & $\mathrm{a}$ & a & $\mathrm{b}$ & $b$ & $\mathrm{~b}$ \\
\hline $\begin{array}{c}\text { Serat Kasar } \\
(\% \pm \text { SE) }\end{array}$ & $5,55 \pm 1,80$ & $4,59 \pm 0,97$ & $3,97 \pm 1,31$ & $4,24 \pm 0,83$ & $3,28 \pm 1,50$ \\
\hline$W=1,11$ & $\mathrm{C}$ & $\mathrm{bc}$ & $a b$ & $a b$ & $\mathrm{a}$ \\
\hline $\begin{array}{c}\text { Derajat Asam } \\
(\mathrm{mL} \mathrm{NaOH} \mathrm{0,1} \mathrm{N/100} \mathrm{g} \\
\pm \mathrm{SE}) \\
\mathrm{W}=1,94\end{array}$ & $\begin{array}{c}2,95 \pm 1,55 \\
a\end{array}$ & $\begin{array}{c}9,27 \pm 0,42 \\
b\end{array}$ & $\begin{array}{c}8,94 \pm 0,56 \\
b\end{array}$ & $\begin{array}{c}8,75 \pm 0,70 \\
b\end{array}$ & $\begin{array}{c}8,70 \pm 1,60 \\
b\end{array}$ \\
\hline $\begin{array}{c}\text { Antioksidan } \\
(\% \pm \text { SE }) \\
W=6,62\end{array}$ & $\begin{array}{c}28,23 \pm 3,99 \\
a\end{array}$ & $\begin{array}{c}48,12 \pm 4,64 \\
C\end{array}$ & $\begin{array}{c}41,17 \pm 4,79 \\
b\end{array}$ & $\begin{array}{c}42,85 \pm 4,89 \\
\text { bc }\end{array}$ & $\begin{array}{c}39,68 \pm 3,97 \\
b\end{array}$ \\
\hline
\end{tabular}

Tabel 1. Rata-rata analisa proksimat tepung ubi jalar dengan berbagai konsentrasi penambahan angkak 


\section{Analisis Statistik}

Data kandungan gizi tepung ubi jalar terfermentasi dianalisis menggunakan rancangan dasar RAK (Rancangan Acak Kelompok), dengan 5 perlakukan dan 5 kali ulangan. Sebagai perlakuan adalah dosis penambahan inokulum angkak yaitu $0 \%$, $5 \%, 10 \%, 15 \%$ dan $20 \%$ sedangkan sebagai kelompok adalah waktu analisis. Pengujian antar rataan perlakuan dilakukan dengan menggunakan Uji Beda Nyata Jujur (BNJ) dengan tingkat kebermaknaan $5 \%$ (Steel and Torie, 1980).

\section{Hasil dan Pembahasan}

Analisa proksimat tepung ubi jalar terfermentasi

Hasil pengukuran kandungan gizi tepung ubi jalar terfermentasi yang meliputi kadar air, kadar abu, karbohidrat, protein, lemak, serat, derajat asam dan antioksidan dapat dilihat pada Tabel 1. Dalam proses pembuatan tepung ubi jalar dilakukan fermentasi dengan angkak yang merupakan produk hasil fermentasi dari Monascus sp. Proses fermentasi akan meningkatkan kandungan air. Peningkatan kandungan air karena adanya proses metabolisme dari mikroba (Dwinaningsih, 2010). Berdasarkan hasil analisa dapat dilihat pada Tabel 1 menunjukkan kandungan kadar air tidak ada perbedaan yang signifikan pada setiap perlakuan. Hal tersebut karena pada proses produksi setelah proses fermentasi selesai, dilanjutkan proses pengeringan dalam drying carbinet pada suhu $50^{\circ} \mathrm{C}$ selama 8 hari sehingga kadar air akan berkurang.

Proses fermentasi akan menguraikan pati dan selulosa menjadi glukosa oleh enzim amilase dan selulase yang dimiliki Monascus $s p$. Glukosa hasil penguraian akan digunakan oleh Monascus $s p$. dalam menunjang pertumbuhan. Enzim amilase berperan dalam mengubah pati menjadi glukosa dengan memutuskan ikatan glukosida yaitu ikatan antara molekul glukosa pada polimer pati. Hasil pemecahan glukosa oleh enzim amilase akan digunakan untuk proses metabolisme. Proses metabolisme dimulai dengan mengolah glukosa menjadi asam piruvat karena proses metabolisme terjadi secara anaerob (fermentasi), maka asam piruvat yang terbentuk akan diubah menjadi produk fermentasi yaitu ATP (Adenosin Tri Phosphate) yang digunakan sebagai sumber energi kapang untuk tumbuh dan berkembang, kemudian hasil lainnya adalah alkohol dan $\mathrm{CO}_{2}$ sebagai hasil metabolisme (Hawusiwa et al., 2015; Chen and Johns, 1994).

Tumbuhnya kapang Monascus akan meningkatkan kandungan protein dalam tepung. Protein yang meningkat selama proses fermentasi dikarenakan adanya pengayaan protein dari sel mikroorganisme. Proses peningkatan kandungan protein karena adanya pembentukan single cell protein atau protein sel tunggal (Litchfield, 1983). Selain itu meningkatnya kandungan protein selama proses fermentasi karena glukosa akan diubah menjadi asam piruvat melalui jalur glikolisis kemudian dari proses glikolisis akan terbentuk senyawa-senyawa intermediet yang selanjutnya melalui proses aminasi maupun transaminasi dapat menghasilkan asam-asam amino. Terbentuk empat jenis asam amino, yaitu serin dibentuk dari sintesis 3-fosfo gliserat, serin akan menghasilkan glisin dan sistein serta alanin yang terbentuk dari asam piruvat yang merupakan produk dari proses glikolisis (Mark et al., 1996). Ketika proses fermentasi selesai antara sel yang tumbuh dengan sisa substratnya tidak dipisahkan atau disebut dengan Microbial Biomass Product (MBP) sehingga protein akan terakumulasi dan terjadi peningkatan kandungan protein (Muhiddin et al., 2001).

Berdasarkan analisis korelasi antara protein dan karbohidrat, maka didapat nilai negatif. Hal tersebut menunjukkan bahwa semakin turunnya karbohidrat akibat proses fermentasi maka kandungan protein akan semakin meningkat. Korelasi antara protein dan karbohidrat tidak signifikan karena proses fermentasi menggunakan inokulum angkak, dimana di dalam angkak sudah memiliki kandungan karbohidrat tertentu. DFG Senate Commission on Food Safety (2013) mengatakan bahwa kandungan karbohidrat pada angkak sebesar $(25-73) \%$. Oleh kerena itu turunnya kandungan karbohidrat akibat proses fermentasi tidak terlihat signifikan.

Proses fermentasi akan mempengaruhi kandungan serat kasar, kadar abu dan lemak. Serat kasar terdiri dari senyawa selulosa, hemi-selulosa dan lignin yang tidak dapat dicerna oleh manusia (Muchtadi, 2001). Wulandari et al. (2013) mengatakan jumlah serat kasar akan mempengaruhi penyerapan nutrisi, ketika suatu bahan pangan memiliki kandungan serat kasar yang tinggi maka serat kasar yang tidak tercerna akan membawa sebagian nutrisi kemudian dikeluarkan bersama fases. Hal ini menyebabkan nilai energi produktif menjadi semakin rendah. Proses fermentasi ubi jalar dengan inokulum angkak terbukti dapat menurunkan kadar serat. Tabel 1 menunjukkan bahwa serat semakin turun seiring dengan penambahan inokulum angkak. Turunnya kandungan serat kasar karena selama proses fermentasi Monascus $s p$. menghasilkan enzim selulase yang dapat menguraikan serat kasar. Serat kasar akan diuraikan menjadi glukosa kemudian dari glukosa yang diperoleh akan digunakan untuk menghasilkan energi (ATP), alkohol dan karbondioksida (Indriawan, 2014).

Hasil pengukuran kadar abu dapat dilihat pada Tabel 1 berdasarkan nilai kadar abu yang diperoleh menunjukkan adanya penurunan seiring dengan pertambahan inokulum angkak. Proses penguraian serat kasar pada tepung ketika fermentasi memiliki hubungan terhadap kadar abu dari sampel. Kurniawan et al. (2013), mengatakan bahwa menurunnya lignin dan serat kasar berhubungan erat dengan menurunnya kadar abu pada suatu bahan pakan. Wibowo (2010), juga menunjukkan bahwa kadar serat kasar dan kadar abu memiliki hubungan yang positif, tingginya serat kasar akan berpengaruh positif terhadap besarnya kadar abu pada suatu bahan.

Berdasarkan analisis korelasi maka diperoleh bahwa kandungan serat pada tepung ubi jalar terfermentasi berkorelasi positif terhadap kadar abu. 
Kadar abu akan turun seiring dengan penurunan serat. Kadar abu yang turun selama proses fermentasi dikarenakan terjadi proses penambahan bahan organik yaitu glukosa akibat kinerja enzim selulase pada Monascus sp. yang mendegradasi selulosa pada substrat ubi jalar (Styawati et al., 2014).

Nilai kadar lemak berbanding terbalik terhadap kadar serat kasar dan kadar abu pada tepung ubi jalar terfermentasi. Semakin banyaknya inokulum yang ditambahkan untuk melakukan proses fermentasi, kadar serat dan kadar abu pada tepung ubi jalar semakin turun, namun kandungan lemak pada tepung ubi jalar terfermentasi malah semakin meningkat.

Berdasarkan analisis korelasi dapat disimpulkan bahwa nilai kandungan lemak pada tepung ubi jalar terfermentasi berkorelasi negatif terhadap kadar serat dan kadar abu, ketika kadar serat dan kadar abu semakin turun akibat fermentasi maka kandungan lemak akan semakin meningkat. Kandungan lemak yang meningkat seiring penambahan inokulum angkak karena di dalam inokulum angkak sudah memiliki kandungan lemak tertentu. DFG Senate Commission on Food Safety (2013) mengatakan bahwa kandungan lemak dalam angkak sebesar $2.84 \%$ dalam 100 gram bahan sehingga semakin banyak penambahan angkak maka kandungan lemak akan terakumulasi dan akan terjadi peningkatan. Selama proses fermentasi berlangsung lemak tidak dengan mudah digunakan karena mikroba lebih cenderung memanfaatkan karbohidrat dan protein terlebih dahulu. Hal tersebut sesuai pendapat Karmani et al. (1996) yang mengatakan bahwa selama proses fermentasi enzim yang pertama kali aktif adalah amilase yang mulai bekerja pada 12 jam pertama, kemudian pada rentang waktu 12-24 jam aktivitas enzim protease mulai maksimal dan pada enzim lipase baru bekerja maksimal pada rentang waktu 24-36 jam.

Selain metabolit primer proses fermentasi Monascus $s p$ juga akan memproduksi senyawa metabolit sekunder berupa monacolin K (lovastatin), citrinin, ankaflavin, monascin, $\gamma$-aminobutyric acid
(GABA) dan lain-lain. Proses metabolit sekunder Monascus sp. menghasilkan pimen yaitu pigmen merah yang mengandung senyawa monacorubramine dan rubropunctamine, pigmen orange mengandung monacorubrin dan rubropunctantin dan pigmen kuning mengandung monascin, ankaflavin, yellow II, dan xanthomonascin A. (Martinkova et al., 1999). Hasil metabolit sekunder lainnya adalah asam demerumic yang bermanfaat sebagai antioksidan yang memiliki kemampuan membersihkan radikal a, a-diphenyl- $\beta$ picrylhydrazyl, mereduksi jenis oksigen seperti super oksida $\left(\mathrm{O}^{2-}\right)$ dan radikal hidroksil $\left(\mathrm{OH}^{-}\right)$. Asam demerumic merupakan komponen utama yang bertangung jawab sebagai senyawa antioksidan (Taira et al., 2002).

Pengukuran aktivitas antioksidan pada tepung ubi jalar terfermentasi dapat dilihat pada Tabel 1 yang menunjukkan terjadinya peningkatan kandungan antioksidan ketika dilakukan penambahan inokulum angkak pada sampel, dan hasil analisa menunjukkan bahwa penambahan inokulum angkak dengan berbagai konsentrasi berpengaruh terhadap kandungan antioksidan dalam sampel. Aktivitas antioksidan dari tepung ubi jalar terfermentasi maksimal pada penambahan angkak $5 \%$, kemudian menurun ketika penambahan $10 \%, 15 \%$ dan $20 \%$. Aktivitas antioksidan yang maksimal pada penambahan angkak $5 \%$ berkaitan dengan kualitas pertumbuhan Monascus $s p$. Monascus sp. akan menghasikan produk metabolisme yang maksimal pada kondisi fermentasi yang sesuai. Salah satu faktor yang mempengaruhi adalah komposisi penambahan inokulum. Penambahan inokulum yang kurang pada suatu substrat menyebabkan fermentasi yang dihasilkan tidak akan maksimal, begitu juga jika penambahan inokulum yang terlalu banyak pada suatu substrat, hasil fermentasi yang diperoleh juga tidak akan maksimal karena akan terjadi perebutan nutrisi (Irdawati, 2010). Pertumbuhan Monascus sp. memiliki beberapa fase, pada fase log Monascus sp. memproduksi metabolit primer kemudian ketika masuk fase stasioner metabolit sekunder akan

Tabel 2. Analisa organoleptik mie basah

\begin{tabular}{|c|c|c|c|c|c|}
\hline \multicolumn{6}{|c|}{ Konsentrasi Penambahan Tepung Ubi Jalar Fermentasi } \\
\hline & $10 \%$ & $20 \%$ & $30 \%$ & $40 \%$ & $50 \%$ \\
\hline \multicolumn{6}{|l|}{ Warna } \\
\hline$(\% \pm \mathrm{SE})$ & $3,60 \pm 0,34$ & $3,24 \pm 0,30$ & $2,76 \pm 0,27$ & $2,24 \pm 0,28$ & $1,76 \pm 0,23$ \\
\hline $\begin{array}{c}\text { BNJ } 5 \% \\
W=0,58\end{array}$ & d & $c d$ & bc & $a b$ & a \\
\hline \multicolumn{6}{|l|}{ Aroma } \\
\hline$(\% \pm \mathrm{SE})$ & $3,36 \pm 0,28$ & $3,04 \pm 0,33$ & $2,44 \pm 0,37$ & $1,92 \pm 0,26$ & $1,8 \pm 0,34$ \\
\hline$W=0,47$ & $\mathrm{c}$ & $\mathrm{c}$ & $\mathrm{b}$ & a & a \\
\hline \multicolumn{6}{|l|}{ Rasa } \\
\hline$(\% \pm \mathrm{SE})$ & $3,44 \pm 0,33$ & $2,68 \pm 0,37$ & $1,96 \pm 0,29$ & $1,72 \pm 0,23$ & $1,72 \pm 0,34$ \\
\hline$W=0,57$ & $\mathrm{c}$ & $\mathrm{b}$ & $\mathrm{a}$ & a & a \\
\hline \multicolumn{6}{|l|}{ Tekstur } \\
\hline$(\% \pm \mathrm{SE})$ & $3,44 \pm 0,31$ & $3,12 \pm 0,28$ & $2,68 \pm 0,31$ & $2,44 \pm 0,36$ & $2,16 \pm 0,27$ \\
\hline$W=0,45$ & $d$ & $\mathrm{~cd}$ & $\mathrm{bc}$ & $a b$ & $\mathrm{a}$ \\
\hline \multicolumn{6}{|l|}{ Keseluruhan } \\
\hline$(\% \pm \mathrm{SE})$ & $3,4 \pm 0,30$ & $2,92 \pm 0,30$ & $2,44 \pm 0,33$ & $2,08 \pm 0,33$ & $1,76 \pm 0,30$ \\
\hline$W=0,47$ & $d$ & $\mathrm{C}$ & $b$ & $a b$ & $\mathrm{a}$ \\
\hline
\end{tabular}


mulai dihasilkan, ketika kondisi pertumbuhan Monascus $s p$. tidak sesuai, proses untuk mencapai fase stasioner akan terhambat akibatnya metabolit sekunder yag dihasilkan juga tidak akan maksimal.

Produksi metabolit sekunder yang maksimal dalam tepung ubi jalar berhubungan dengan derajat asam. Berdasarkan hasil analisis korelasi dapat disimpulkan bahwa hubungan antara derajat asam dan antioksidan memiliki korelasi yang positif hal ini menunjukkan bahwa selama fermentasi ketika kandungan antioksidan meningkat, derajat asam juga akan semakin meningkat dan sebaliknya ketika antioksidan menurun maka kandungan derajat asam juga turun. Kandungan asam yang meningkat dikarenakan adanya penambahan asam-asam organik ketika proses fermentasi berlangsung. Peningkatan nilai asam menunjukkan adanya akifitas dari Monascus $s p$. dalam mengkonversi zat tepung menjadi berbagai macam hasil metabolisme (Nufus, 2013). Semakin meningkatnya kandungan asam maka akan semakin menurunkan nilai $\mathrm{pH}$, Lee et al. (2001) mengatakan bahwa $\mathrm{pH}$ memiliki pengaruh terhadap pertumbuhan sel Monascus sp. dan kemampuan memproduksi senyawa metabolit sekunder.

Proses fermentasi angkak yang dapat meningkatkan kandungan antioksidan dan derajat asam yang berhubungan terhadap kualitas pertumbuhan Monascus sp. Monascus sp. adalah jenis protein sel tunggal atau single cell protein maka semakin tinggi nilai protein pada sampel tepung ubi jalar terfermentasi semakin banyak juga mikroba yang tumbuh dalam sampel tersebut. Berdasarkan hasil analisis korelasi dapat dilihat bahwa antioksidan dan derajat asam memiliki korelasi yang positif terhadap protein. Hal ini menunjukkan bahwa semakin tingginya mikroorganisme yang tumbuh pada substrat maka kandungan antioksidan, protein serta derajat asam semakin meningkat, begitu pula sebaliknya ketika Monascus sp. yang tumbuh tidak maksimal maka kandungan protein, antioksidan dan derajat asam juga tidak akan maksimal.

\section{Analisa Organoleptik Mie Basah}

Tepung ubi jalar terfermentasi dapat diaplikasikan menjadi mie basah hingga subtitusi $50 \%$. Produk mie basah yang dihasilkan dilakukan pengujian organoleptik dengan uji hedonik (kesukaan) terhadap 25 panelis. Uji hedonik dilakukan pada parameter rasa, warna, aroma, dan tekstur. Hasil pengujian organoleptik dapat dilihat pada Tabel 2 dengan diagram laba-laba yang ditunjukkan pada Gambar 1.

Berdasarkan hasil analisis organoleptik pada parameter warna, aroma, rasa, tekstur dan penilaian secara keseluruhan menunjukkan penilaian panelis tertinggi pada subtitusi $10 \%$ dengan nilai parameter warna 3,60 (agak suka), parameter aroma 3,36 (agak suka), parameter rasa 3,44 (agak suka), parameter tekstur 3,44 (agak suka) serta penilaian secara keseluruhan memperoleh nilai 3,4 (agak suka).

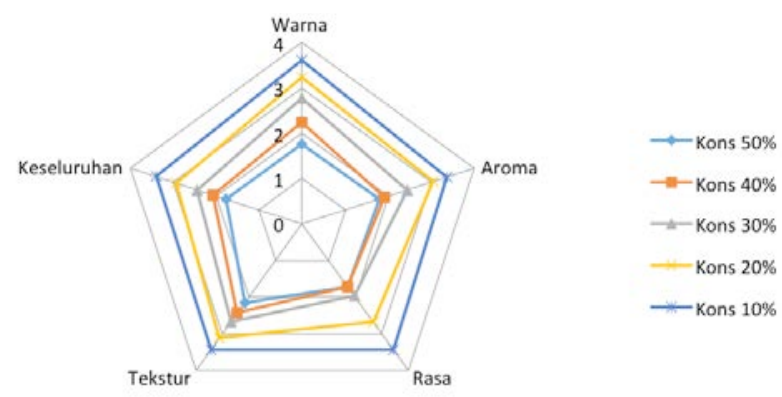

Gambar 1. Diagram laba-laba uji organoleptik mie basah

\section{Kesimpulan}

Ditinjau dari nisbah substrat ubi jalar dan penambahan inokulum angkak, maka tepung ubi jalar terfermentasi yang optimal diperoleh dengan penambahan inokulum angkak 5\%. Penambahan inokulum angkak dengan dosis $5 \%$ dapat meningkatkan kandungan protein, lemak, derajat asam, antioksidan serta menurunkan karbohidrat, serat dan kadar abu Tepung ubi jalar terfermentasi dapat diaplikasikan menjadi mie basah hingga subtitusi $50 \%$. Uji organoleptik yang paling disukai dari segi warna, rasa, aroma, tekstur dan keseluruhan pada subtitusi $10 \%$.

\section{Ucapan Terimakasih}

Penelitian ini didanai oleh PT. Indofood Sukses Makmur Tbk. melalui program Indofood Riset Nugraha (IRN) 2015/2016.

\section{Daftar Pustaka}

Chen, M.-H. \& Johns, M.R., 1994. Effect of carbon source on ethanol and pigment production by Monascus purpureus. Enzyme Microb. Technol (16):584-590.

DFG Senate Commission on Food Safety, 2013. Toxicological evaluation of red mould rice, Technische Universitat Kaiserslautern, Kaiserslautern.

Dwinaningsih, E.A., 2010. Karakteristik Kimia dan Sensori Tempe dengan Variasi Bahan Baku Kedelai/Beras dan Penambahan Angkak Serta Variasi Lama Fermentasi. Skripsi, Universitas Sebelas Maret, Surakarta.

Hawusiwa, E.S., Wardani, A.K. \& Ningtyas, D.W., 2015. Pengaruh Konsentrasi Pasta Singkong (Manihot esculenta) Dan Lama Fermentasi Pada Proses Pembuatan Minuman Wine Singkong. Jurnal Pangan dan Agroindustri (3): 147-155.

Irdawati, 2010. Pengaruh Jumlah Starter Dan Waktu Fermentasi Terhadap Pigmen Yang Dihasilkan Oleh Monascus Purpureus Pada Limbah Ubi Kayu (Manihot Utillisima). Eksakta (1): 19-24.

Indriawan, A., 2014. Pengaruh Suhu Terhadap Aktivitas Selulase Isolat Bakteri Usus Itik (Anas Domestica) Sebagai Kandidat Probiotik. Skripsi, Universitas Lampung, Lampung.

Karleen, S., 2010. Optimasi Proses Pembuatan Tepung Ubi Jalar Ungu (Ipomoea batas (L.)Lam) dan Aplikasinya Dalam Pembuatan Keripik Simulasi 
(SIMULATED CHIPS). Skripsi, Institut Pertanian Bogor, Bogor.

Karmani, M., Sutopo, D. \& Hermana, H., 1996. Aktivitas Enzim Hidrolik Kapang Rhizopus Sp Pada Proses Fermentasi Tempe. Jurnal Penelitian Gizi dan Makanan (19): 93-102.

Kurniawan, B., Fathul, F. dan Widodo, Y., 2013. Delignifikasi Pelepah Daun Sawit Akibat Penambahan Urea, Phanerochaete chrysosporium Dan Trametes sp. terhadap Kadar Abu, Kadar Air, Kadar Protein, Kadar Lemak dan Bahan Ekstrak Tanpa Nitrogen (BETN). Universitas Lampung. P.1-5.

Kusumawati, T.H., Suranto dan Setyaningsih, R., 2005. Kajian Pembentukan Warna pada MonascusNata Kompleks dengan Menggunakan Kombinasi Ekstrak Beras, Ampas Tahu dan Dedak Padi sebagai Media. Biodiversitas(60): 160-163.

Lee, B.-K., Park, N.-H., Piao, H.Y. and Chung, W.-J., 2001. Production of Red Pigments by Monascus purpureus in Submerged Culture. Biotechnol. Bioprocess Eng (6): 341-346.

Litchfield, J.H., 1983. Single-Cell Proteins. Science (219): $740-746$

Mark, D.B., D.Mark, A. \& M.smith, C., 1996. Biokimia Kedokteran Dasar. EGC,Jakarta.

Martinkova et al., 1999. Biological activities of oligoketide pigments of Monascus purpureus. Food Additives and Contaminants (16):15-24.

Muchtadi, D., 2001. Sayuran Sebagai Sumber Serat Pangan Untuk Mencegah Timbulnya Penyakit Degeneratif. Jurnak Teknologi dan Industri Pangan(12) : 61-71.

Muhiddin, N.H., Juli, N. \& Aryantha, I.N.P., 2001. Peningkatan Kandungan Protein Kulit Umbi Ubi Kayu Melalui Proses Fermentasi. JMS(6):1-12.

Nufus, H., 2013. Pengaruh Konsentrasi Inokulum Monascus Purpureus Terhadap Produksi Pigmen Pada Substrat Tepung Biji Durian. Bandung: Universitas Pendidikan Indonesia.

Nuraini, Sabrina dan Latif, S.A., 2009. Kondisi Optimum Dan Profil Produk Fermentasi Dengan Monascus Purpureus Dengan Substrat Limbah Agro Industri Sebagai Pakan Alternatif Ternak Unggas. Artikel Penelitian Strategis Nasional. Universitas Andalas Padang, Padang.
Prabowo, T.T., 2009. Uji Aktivitas Antioksidan Dari Keong Mata Merah (Cerithidea Obtusa). Skripsi. Institut Pertanian Bogor, Bogor.

Rusli, R.K., 2011. Pemberian Campuran Dedak Dan Ampas Tahu Fermentasi Dengan Monascus Purpureus Terhadap Performa Dan Kualitas Telur Ayam. Tesis. Universitas Andalas, Padang.

Taira, J., Miyagi, C. \& Aniya, Y., 2002. Dimerumic acid as an antioxidant form the mold, Monascus anka: the inhibition mechanisms against lipid peroxidation and hemeprotein-mediated oxidation. Biochemical Pharmacology (63):10191026.

SNI, 1992. SNI 01 -2891-1992 : Cara Uji Makanan dan Minuman. Badan Standardisasi Nasional, Jakarta.

SNI, 2011. SNI 7622-2011 : Tepung Mokaf. Badan Standardisasi Nasional, Jakarta.

Steel, R. \& Torie, J.H., 1980. Prinsip dan Prosedur Statitiska Suatu Pendekatan Biometrik. Gramedia, Jakarta.

Styawati, N.E., Muhtarudin dan Liman, 2014. Pengaruh Lama Fermentasi Trametes Sp. Terhadap Kadar Bahan Kering, Kadar Abu, Dan Kadar Serat Kasar Daun Nenas Varietas Smooth Cayene. Universitas Lampung, Lampung.

Sudarmadji, S., Haryono, B. dan Suhardi, 1997. Prosedur Analitik Untuk Bahan Makanan dan Pertanian. Liberty, Yogyakarta.

Suslina, Latif, N., Mirzah dan Djulardi, A., 2011. Pengaruh Campuran Ampas Sagu Dan Ampas Tahu Fermentasi Dengan Kapang Monascus purpureus Dalam Ransum Terhadap Kualitas Telur Puyuh. Embrio(4):18-25.

Wibowo, A.H., 2010. Pendugaan Kandungan Nutrien Dedak Padi Berdasarkan Karakteristik Fisik. In Tesis. Bogor: Institut Pertanian Bogor.

Wulandari, K.Y., Ismadi, V.D.Y.B. \& Tristiarti, 2013. Kecernaan Serat Kasar Dan Energi Metabolis Pada Ayam Kedu Umur 24 Minggu Yang Diberi Ransum Dengan Berbagai Level Protein Kasar Dan Serat Kasar. Animal Agriculture Journal(2): 9-17.

Zuraida, N. dan Supriati, Y., 2001. Usahatani Ubi Jalar sebagai Bahan Pangan Alternatif dan Diversifikasi Sumber Karbohidrat. Buletin AgroBio(4):13-23. 